\title{
PROSES PERUMUSAN KEBIJAKAN ANGGARAN PENDAPATAN DAN BELANJA DAERAH KABUPATEN SUMEDANG
}

\author{
Rudiana \\ Staf Pengajar Prodi Ilmu Pemerintahan Fakultas Ilmu Sosial dan Ilmu Politik \\ Universitas Padjadjaran \\ Email: Rudiana1974@gmail.com
}

\begin{abstract}
ABSTRAK
FenomenakebijakanAPBD disebagian besardaerah kurangmempertimbangkan aspek kepentingan masyarakat. Hal ini berbeda dengan Pemerintah Kabupaten Sumedang yang melibatkan masyarakat dalam proses perumusannya. Proses perumusan kebijakan Anggaran Pendapatan dan Belanja Daerah Kabupaten Sumedang, menjadi judul dari penelitian ini.

Metode yang digunakan dalam penelitian ini adalah metode deskriptif dengan pendekatan kualitatif. Teknik pengumpulan data yang digunakan adalah studi pustaka dan studi lapangan, yang berupa observasi, wawancara, dan dokumentasi. Teknik penentuan informan menggunakan teknik purposive. Penelitian ini dilakukan di DPRD Kabupaten Sumedang, Pemerintah Kabupaten Sumedang, dan Forum Delegasi Musrenbang (FDM).

Berdasarkan hasil penelitian di lapangan, dapat diketahui bahwa tahapan dalam proses perumusan kebijakan adalah perumusan masalah kebijakan, penyusunan agenda kebijakan, pemilihan alternatif kebijakan, dan pengesahan kebijakan. Selain itu hal yang menarik didalam proses perumusan kebijakan APBD Kabupaten Sumedang ini adalah katerlibatan lembaga lain selain pemerintah dan DPRD yaitu FDM (Forum Delegasi Musrenbang). FDM akan mengawal keput usan hasil musrenbang hingga masuk kedalam pembahasan APBD. Sehingga dilihat dari prosesnya didalam kebijakan APBD Kabupaten Sumedang ini telah sesuai dengan harapan dan kepentingan masyarakat.

Mengingat pentingnya perumusan kebijakan dalam menyelesaikan suatu permasalahan dalam masyarakat, maka Pemerintah Kabupaten Sumedang harus membuat suatu kebijakan APBD yang dapat menyelesaikan masalah publik. Keterbukaan dan pola akomodatif yang luas terhadap partisipasi masyarakat dalam perumusan kebijakan APBD harus tetap dipertahankan karena hal itu dapat
\end{abstract}


meminimalisir penyimpangan-penyimpangan yang biasa terjadi dalam perumusan anggaran Daerah Kabupaten Sumedang. Hal ini merupakan awal yang positif dalam upaya membangun good governance pada pemerintahan Kabupaten Sumedang. FDM dan DPRD harus dapat membangun komunikasi yang intensif agar tidak menimbulkan konflik diantara kedua lembaga lokal tersebut. Karena baik DPRD dan FDM merupakan representasi masyarakat yang sama-sama meperjuangkan kepentingan masyarakat dalam perumusan anggaran di Kabupaten Sumedang.

Kata Kunci : Perumusan Kebijakan, APBD

\section{ABTRACT}

In most areas of the budget (APBD) policy Phenomenon is less to consider aspects of the public interest. This is different from Sumedang District Government involving the community in the process of its formulation. The process of policy formulation APBD Sumedang regency, became the title of this study.

The method used in this research is descriptive method with qualitative approach. Data collection techniques used are literature studies and field studies in the form of observations, interviews, and documentation. Determination techniques informants using purposive technique. This research was conducted in DPRD Sumedang, Sumedang District Government, and Forum delegation Musrenbang ( FDM ).

Based on the results of research in the field, it can be seen that the stages in the process of policy formulation is the formulation of a policy issue, policy agenda, election of policy alternatives, and approval policies. Besides the interesting things in the process of policy formulation Sumedang district APBD is involvement other institutions besides the government and parliament that FDM (Forum Delegation Musrenbang). FDM will oversee the results musrenbang decision to enter into the discussion of budget. So the views of the process in Sumedang district budget (APBD) policy has been in line with expectations and interests of the community.

Given the importance of the formulation of policies in solving problems in society, the Sumedang District Government should create a budget policy that can resolve public problems. Openness and patterns of accommodating a broad commitment to public participation in the formulation of budget policy should be maintained because it can minimize the aberrations that are common in budget formulation Sumedang regency. This is a positive start to building good governance in Sumedang. FDM district government and the DPRD should be able to establish 
an intensive communication in order to avoid conflict between the two local agencies. Since both Parliament and FDM is a representation of society that are equally fighting for the interests of society in the formulation of the budget in Sumedang .

Keywords: Public Policy, APBD

\section{PENDAHULUAN}

\section{Latar Belakang}

Kegagalan pola pemerintahan sentralistik dan otokratik pada era orde baru, telah memunculkan kesadaran kolektif akan pentingnya pola pemerintahan yang desentralistik dan demokratis. Kegagalan tersebut ditandai dengan lahirnya reformasi dan jatuhnya pemerintahan orde baru. Salah satu alasan jatuhnya rezim orde baru dikarenakan dominasi pemerintah pusat terhadap pemerintahan daerah. Seperti dalam hal perumusan kebijakan anggaran, pemerintah daerah tidak memiliki peranan yang berarti dalam proses perumusan kebijakan anggaran, sebab proses kebijakan anggaran didominasi pemerintah pusat. Sehingga kebijakan anggaran pada pemerintah daerah tidak mencerminkan tuntutan dari kebutuhan daerah tapi berorientasi pada kepentingan pemerintah pusat di daerah.

Gerakan reformasi yang menggulingkan kekuasaan Orde Baru turut berpengaruh didalam perkembangan perundang-undangan pemerintahan daerah. Salah satu pengaruh tersebut adalah kelahiran Undangundang No. 22 tahun 1999 tentang
Pemerintahan Daerah dan Undangundang No.25 tahun 1999 tentang Perimbangan Keuangan Pusat dan Daerah. Undang-undang tersebut merupakan blue print pembangunan untuk membenahi penyelengaraan pemerintahan yang sebelumnya lebih menekankan peran pusat dalam setiap upaya pembangunan wilayah, pelayanan publik, dan pemberdayaan masyarakat.

Kedua Undang-undang ini memperkenalkan konsep otonomi daerah yang lebih mengedepankan demokratisasi lokal, penguatan partisipasi publik, pemerataan dan keadilan pembangunan yang berbasis pada potensi dan perbedaan daerah, serta penguatan peran DPRD sebagai lembaga representasi masyarakat daerah. Hal tersebut dilakukan dengan memberikan hak otonomi kepada pemerintah daerah, dimana pemerintah daerah mempunyai hak untuk mengurus dan mengelola daerahnya sendiri. Dengan adanya konsep otonomi ini diharapkan didalam proses perumusan kebijakan khususnya yang menyangkut penganggaran, bisa mempermudah daerah dalam mengakselerasikan pembangunan daerah sesuai kemampuan daerahnya. 
Partisipasi tersebut diwujudkan dengan memberi ruang partisipasi masyarakat dalam proses perumusan kebijakan terutama mengenai anggaran melalui Musyawarah Rencana Pembangunan (Musrenbang). Melalui wadah inilah aspirasi masyarakat dapat dijaring sehingga isi dari kebijakan tersebut repsesentatif dengan kebutuhan masyarakat di tingkat daerah. Jaminan adanya ruang partisipasi publik dalam perencanaan dituangkan dalam Undang-undang Sistem Perencanaan Pembangunan Nasional No. 25 Tahun 2004 yang didalamnya mengamanatkan adanya suatu forum kosultasi publik dalam proses perencanaan pembangunan di setiap unit pemerintahan. Forum tersebut yang dikenal dengan istilah Musyawarah Rencana Pembangunan (Musrenbang) yang ada pada tingkat desa/kelurahan, kecamatan, kota/ kabupaten sampai tingkat nasional. Dalam sistem politik yang demokratis sistem tersebut diharapkan menjadi arena komunikasi timbal balik antara lembaga perencana dengan pemangku kepentingan (stakeholders) untuk menetapkan keputusan kolektif.

Secara teoritis gagasan-gagasan perubahan yang dianut oleh kedua Undang-undang tersebut telah membuka ruang publik yang positif bagi masyarakat lokal untuk dapat mengembangkan sendiri daerahnya masing-masing. Didalamnya diatur suatu sistem proses perumusan kebijakan terutama anggaran yang harus melalui Musrenbang sebagai wujud dari keterbukaan ruang publik didalam proses perumusan kebijakan anggaran bottom up. Namun didalam praktiknya ruang publik tersebut tidak berjalan seperti yang diharapkan karena kultur aparat pemerintah yang masih dipengaruhi oleh kultur top down aparat. Hal ini dikarenakan masih melekatnya kebiasaan-kebiasaan di jaman pemerintahan Orde Baru yang kemudian terbawa ke jaman Reformasi.

Untuk itu maka pemerintah menyempurnakan kembali sistem pemerintahan daerah yang diundangkan dalam Undang-Undang No 23 Tahun 2014 sebagai pengganti Undang-Undang No.32 tahun 2004 tentang Pemerintahan Daerah. Hal tersebut merupakan salah satu faktor penting dalam menunjang keberhasilan penyelenggaraan otonomi daerah yaitu proses formulasi kebijakan (fungsi mengatur).

Paradigma baru penyelenggaraan otonomi daerah di Indonesia pada dasarnya dilandasi oleh prinsip-prinsip demokrasi lokal dan good governance. Dengan landasan tersebut maka pemerintah daerah dan DPRD sebagai institusi lokal yang mengemban tanggung jawab penyelenggaraan otonomi daerah yang merupakan perwujudan dari representasi masyarakat local. Pergeseran kekuasaan dari pusat ke daerah dan pemberdayaan DPRD, setidak-tidaknya telah membentuk dinamika tersendiri dalam hubungan pemerintah daerah dan DPRD yang 
seringkali diwarnai oleh konflik dan juga syarat dengan nuansa kong-kalikong.

Selain konflik yang terjadi dalam tubuh sistem pemerintahan, konflikpun terjadi dalam ranah sistem keuangan. Sistem keuangan daerah sendiri diatur didalam UndangUndang No. 33 tahun 2004 tentang Perimbangan Keuangan antara Pemerintah Pusat dan Pemerintahan Daerah. Undang-undang tersebut kemudian dipertegas melalui permendagri 13 tahun 2006 tentang pedoman pengelolaan keuangan daerah yang selanjutnya menjadi panduan didalam proses perumusan kebijakan Anggaran Pendapatan dan Belanja Daerah di seluruh Indonesia.

Jenis konflik yang terjadi adalah pada tahap pencarian kesepakatan untuk ditetapkan menjadi APBD, yang terjadi adalah tarik menarik kepentingan diantara pemerintah daerah dan DPRD. Dengan demikian maka maka kepentingan pemerintah daerah dan DPRD yang akan mendapat prioritas utama karena kepentingannya bisa diperjuangkan pada tahapan akhir. Sementara hasil Musrenbang hanya dijadikan alternatif dari tarikmenarik kepentingan diantara pemerintah daerah dan DPRD. Hal ini dikarenakan kepentingan masyarakat yang diakomodasikan melalui Musrenbang ini tidak ada yang menjamin untuk memperjuangkannya sampai pada tahapan penetapan kebijakan APBD.
Gambaran di atas menunjukan bahwa keterlibatan masyarakat dalam proses perencanaan dan penganggaran hanya sebatas formalitas partisipatif. Keterlibatan masyarakat dalam perumusan kebijakan anggaran hanya sebagai syarat prosedural dalam penyusunan anggaran tanpa menyentuh substansinya.

Untuk meredam konflik kepentingan yang terjadi antara Peremintah Daerah, DPRD dan rendahnya partisipasi masyarakat, maka pemerintah Kabupaten Sumedang memiliki teroboson dengan memperkuat dan memperluas peran partisipasi civil society di Kabupaten Sumedang. Payung hukum yang dikeluarkan oleh Pemerintah Kabupaten Sumedang adalah Perda No 1 Tahun 2007 tentang prosedur perencanaan dan penganggaran daerah Kabupaten Sumedang. Perda ini memuat berbagai terobosan inisiatif kebijakan penganggaran, dimana pagu Indikatif sektoral dan kecamatan mulai diperkenalkan dan dipergunakan sebagai rancangan awal program prioritas dan patokan batas maksimal anggaran yang diberikan kepada SKPD Dinas pemerintahan Kabupaten hingga SKPD kecamatan.

Selain itu dalam perda ini juga melembagakan sebuah forum masyarakat yang dibentuk untuk mewadahi delegasi masyarakat wilayah kecamatan sebagai representasi dari delegasi masyarakat wilayah desa yang ada di Kabupaten Sumedang. Forum masyarakat ini dibentuk 
setelah penyelenggaraan musrenbang kabupaten. Forum masyarakat ini dikenal dengan sebutan Forum Delegasi Musrenbang atau yang disingkat dengan FDM.

Fungsi yang utama dari Forum Delegasi Musrenbang (FDM) adalah sebagai media pengawasan masyarakat terhadap proses penyusunan APBD sampai pada tahap Implementasi APBD. Sehingga kepetingan masyarakat yang dijaring melalui musrenbang dapat diawasi dari proses perumusan di musrenbang, penetapan, hingga implementasi mengenai penganggaran yang menyangkut kepentingan masyarakat yang dijaring melalui Musrenbang di Kabupaten Sumedang. Dengan demikian keberadaan Forum Delegasi Musrenbang ini menunjukan adanya partisipatif yang nyata dari masyarakat.

Untuk itu maka penulis merasa tertarik untuk dapat melakukan penelitian di bidang Proses perencanaan dan penganggaran daerah Kabupaten Sumedang. Dimana suatu langkah atau terobosan baru dari pemerintah Kabupaten Sumedang ini merupakan suatu keberhasilan dari sistem perencanaan dan penganggaran yang partisipatif. Hal itu menunjukan hal yang positif yang memerlukan kajian ilmiah supaya memiliki nilai positif atau nilai tambahan yang secara praktis dapat dijadikan acuan pemerintah daerah lain. Selain itu secara akademis dapat dijadikan sebuah konsep baru dalam membangun dan menata sistem pemerintahan daerah dimasa kini dan masa yang akan datang.

Berdasarkan uraian diatas maka fokus permasalahan yang akan dikaji oleh penulis tuangkan dalam pertanyaan penelitian sebagai berikut: Bagaimanakah proses perumusan Anggaran Pendapatan dan Belanja Daerah Kabupaten Sumedang?

\section{TINJAUAN PUSTAKA}

\section{Perumusan Kebijakan Publik}

Definisi perumusan kebijakan dengan pembuatan kebijakan itu berbeda, oleh sebab itu Winarno mengutip pendapat Anderson yang membuat kategorisasi untuk berbagai konsep dalam kebijakan publik. Menurut Anderson ${ }^{25}$ :

"Perumusan kebijakan menyangkut upaya untuk menjawab pertanyaan bagaimana berbagai

25 Budi Winanrno. Teori dan Proses Kebijakan Publik. Yogyakarta : Media Pressindo. Depok, hal $89-70$

$44 \mid$ Cosmogov, Vol. 2 No. 1, April 2016 
alternatif disepakati untuk masalah-masalah yang dikembangkan dari siapa yang berpartisipasi. Ia merupakan proses yang secara spesifik ditunjukkan untuk menyelesaikan persoalanpersoalan khusus. Sedangkan pembentukan kebijakan lebih merujuk pada aspek-aspek seperti misalnya, bagaimana masalahmasalah publik menjadi dirumuskan untuk masalah-masalah khusus, dan bagaimana proposal tersebut dipilih diantara berbagai alternatif yang saling berkompetisi".

Dalam hal tersebut Winarno menambahkan bahwa: "Pembuatan kebijakan merupakan keseluruhan tahap dalam kebijakan publik yang berupa rangkaian keputusan" 26 .

Perumusan kebijakan publik pada dasarnya akan mudah dipelajari apabila menggunakan suatu pendekatan atau model tertentu. Para ahli politik telah mengembangkan berbagai macam model atau pendekatan yang dapat membantu kita dalam memahami kehidupan politik, pemerintahan, proses perumusan kebijakan dan sebagainya.
Sebelum sampai pada penjelasan masing-masing model, perlu dikemukakan terlebih dahulu bahwa tidak satupun dari berbagai macam model yang dibahas dianggap paling baik, karena masing-masing model memberikan fokus perhatiannya pada kehidupan politik yang berbeda, sehingga dapat membantu kita dalam mempelajari kebijakan publik dari berbagai sudut pandang.

Dari beragamnya model kebijakan secara singgat penelitian ini menggunkaan Model Mixed-scanning. Model ini yang merupakan "gabungan antara unsur-unsur kebaikan yang ada pada model rasional-komprehensif dan model inkremental"27. Model ini memanfaatkan dua macam pendekat an yang telah ada sebelumnya secara fleksibel. Dalam beberapa hal pendekatan rasional-komprehensif akan diterapkan apabila diperlukan penjelajahan dan pengamatan yang luas, sedangkan pada beberapa hal lain pendekatan inkremental akan diterapkan apabila diperlukan pengamatan yang mendetail pada suatu objek atau sasaran.

Model-model pembuatan kebijakan publik dapat digunakan untuk

26. Ibid., hal 70

27. Irfan Islamy. Prinsip-Prinsip Perumusan Kebijakan Negara. 2004. Jakarta : Bina Aksara., hal 70 
mengetahui dan menganalisa faktorfaktor apa yang menjadi latar belakang pertimbangan pembuat suatu keputusan, syarat-syarat yang harus dipenuhi untuk dapat membuat atau merumuskan suatu kebijakan serta polapola apa saja yang digunakan oleh para aktor pembuat kebijakan dalam pengambilan keputusan dari suatu kebijakan.

\section{Tahapan dalam Perumusan Kebijakan}

Sebagai bentuk dari suatu usaha membentuk hasil kebijakan yang optimal dan dapat dirasakan oleh seluruh lapisan masyarakat, maka Budi Winarno dalam bukunya Teori dan Proses Kebijakan Publik, memaparkan beberapa tahap dalam perumusan kebijakan, antara lain ${ }^{28}$ :

1. Perumusan Masalah.

2. Agenda Kebijakan.

3. Pemilihan Alternatif Kebijakan Untuk Memecahkan Masalah.

4. Tahap Penentuan Kebijakan.

Tahapan-tahapan perumusan tersebut dapat lebih dijelaskan pada tabel dibawah ini:

Tabel 1.1 Tahap-Tahap Dalam Proses Perumusan Kebijakan

\begin{tabular}{|l|l|l|}
\hline Tahap & \multicolumn{1}{|c|}{ FASE } & \multicolumn{1}{c|}{ KARAKTERISTIK } \\
\hline 1 & Perumusan Masalah & $\begin{array}{l}\text { Untuk dapat merumuskan kebijakan dengan baik, } \\
\text { maka masalah-masalah publik harus dikenali dan } \\
\text { didefinisikan dengan baik pula. Kebijakan publik } \\
\text { pada dasarnya dibuat untuk memecahkan masalah } \\
\text { yang ada dalam masyarakat. }\end{array}$ \\
\hline 2 & Agenda Kebijakan & $\begin{array}{l}\text { Tidak semua masalah publik akan masuk kedalam } \\
\text { agenda kebijakan. Masalah-masalah tersebut } \\
\text { saling berkompetensi antara satu dengan yang } \\
\text { lain. Hanya masalah-masalah tertentu yang pada } \\
\text { akhirnya akan masuk ke dalam agenda kebijakan. } \\
\text { Suatu masalah agar masuk kedalam agenda } \\
\text { kebijakan harus mematuhi syarat tertentu, seperti } \\
\text { misalnya apakah masalah tersebut mempunyai } \\
\text { dampak yang sangat besar bagi masyarakat dan } \\
\text { membutuhkan penanganan yang harus segera } \\
\text { dilakukan. Masalah yang telah masuk kedalam } \\
\text { agenda kebijakan akan dibahas oleh para perumus } \\
\text { kebijakan, seperti kalangan legislatif (DPR), } \\
\text { kalangan eksekutif, agen-agen pemerintah dan } \\
\text { mungkin juga kalangan yudikatif. Masalah- } \\
\text { masalah tersebut dibahas berdasarkan tingkat } \\
\text { urgensinya untuk segera diselesaikan. Agenda }\end{array}$ \\
\hline
\end{tabular}

28. Budi Winanrno. Op.Cit, hal 82-84 


\begin{tabular}{|c|c|c|}
\hline & & $\begin{array}{l}\text { kebijakan itu sendiri didefinisikan sebagai } \\
\text { tuntutan-tuntutan agar para pembuat kebijakan } \\
\text { memilih atau merasa terdorong untuk malakukan } \\
\text { tindakan tertentu. Berbicara penyusunan agenda } \\
\text { kebijakan dalam lembaga dewan/legislatif maka } \\
\text { secara langsung pada akhirnya berbicara juga } \\
\text { masalah politik, walaupun tidak semua pakar } \\
\text { kebijakan menyatakan bahwa agenda kebijakan } \\
\text { merupakan bagian dari tuntutan-tuntutan politik. } \\
\text { Ketika suatu masalah publik telah masuk kedalam } \\
\text { agenda para perumus kebijakan, maka masalah } \\
\text { tersebut akan diidentifikasikan menurut dua } \\
\text { macam agenda kebijakan, yakni agenda sistematik } \\
\text { dan agenda lembaga atau pemerintah. }\end{array}$ \\
\hline 3 & $\begin{array}{l}\text { Pemilihan Alternatif } \\
\text { Kebijakan Untuk } \\
\text { Memecahkan Masalah }\end{array}$ & $\begin{array}{l}\text { Setelah masalah-masalah publik didefinisikan } \\
\text { dengan baik dan para perumus kebijakan, maka } \\
\text { langkah selanjutnya adalah pemecahan masalah. } \\
\text { Disini para perumus kebijakan akan berhadapan } \\
\text { dengan alternatif-alternatif pilihan kebijakan } \\
\text { yang dapat diambil untuk memecahkan masalah } \\
\text { tersebut. Adanya pertarungan kepentingan ini } \\
\text { dalam suatu lembaga pemerintahan dan politik } \\
\text { adalah suatu hal yang wajar, sebab setiap } \\
\text { lembaga pemerintahan atau politik akan berusaha } \\
\text { menunjukkan eksistensi kekuasaannya dengan } \\
\text { selalu melahirkan atau mengusulkan kebijakan } \\
\text { yang tentunya berbeda dengan pihak lain. } \\
\text { Untuk mengantisipasi pertarungan kepentingan } \\
\text { yang tidak berkesudahan,dan perlunya suatu } \\
\text { koordinator. Penyampaian saran atau tujuan } \\
\text { rekomendasi kebijakan dilakukan dengan } \\
\text { bersahaja berdasarkan suatu kajian yang spesifik. } \\
\text { Artinya, suatu alternatif kebijakan yang dipilih } \\
\text { untuk disarankan telah dihitung nilai lebihnya } \\
\text { dibandingkan dengan berbagai alternatif lain yang } \\
\text { mungkin dapat dilakukan }\end{array}$ \\
\hline 4 & $\begin{array}{l}\text { Tahap Penentuan } \\
\text { Kebijakan }\end{array}$ & $\begin{array}{l}\text { Setelah itu dari sekian alternatif kebijakan } \\
\text { diputuskan diambil sebagai cara untuk } \\
\text { memecahkan masalah kebijakan, maka tahap } \\
\text { paling akhir dalam pembuatan kebijakan adalah } \\
\text { menetapkan atau mengesahkan kebijakan yang } \\
\text { dipilih tersebut sehingga mempunyai kekuatan } \\
\text { hukum yang mengikat". }\end{array}$ \\
\hline
\end{tabular}




\section{Aktor-Aktor dalam Perumusan Kebijakan}

Aktor-aktor atau pemeran serta dalam proses pembuatan kebijakan dapat dapat dibagi ke dalam dua kelompok, yaitu ${ }^{29}$ :

"Para pemeran serta resmi dan para pemeran serta tidak resmi. Yang termasuk ke dalam pemeran serta resmi adalah agen-agen pemerintah (birokrasi), presiden (eksekutif), legislatif, dan yudikatif. Sedangkan yang termasuk ke dalam kelompok pemeran serta tidak resmi meliputi: kelompok-kelompok kepentingan, partai politik, dan warga negara individu".

Menurut Anderson, Pirley, dan Guy Peter dalam Sugiono yang dikutip Solahuddin ${ }^{30}$ :

"Didalam proses studi kebijakan aktor-aktor berasal dari dari berbagai macam lembaga yang tercakup didalam supra struktur politik dan infra struktur politik. Para ahli mengidentifikasi aktoraktor dengan berbagai macam sebutan yaitu: legislator, eksekutif, lembaga peradilan, kelompok penekan, partai politik, media massa, organisasi komunitas, aparat administrasi atau birokrasi, kelompok non gevernmental (NGO) kelompok swasta, dan kelompok thing thanks, dan kabinet bayangan".

Hal tersebut mempertegas penyataan Winarno dimana ada menurutnya ada lembaga resmi dan tidak resmi. Lembaga resmi ini meliputi lembaga pemerintah yang berwenang didalam proses perumusan kebijakan yang diistilahkan dalam Solahhudin sebagai suprastruktur politik. Sementara lembaga tidak resmi yaitu lembaga non pemerintah yang memiliki kekuatan dan bisa mempengaruhi didalam proses perumusan kebijakan.

\section{Perencanaan dan Penganggaran Daerah}

Rumusan mengenai perencanaan ditemukan pada berbagai literature. Salah satu pengertian perencanaan dirumuskan sebagai suatu kegiatan pendahuluan yang harus dilakukan sebelum kegiat an pokok dilaksanakan. Perencanaan diperlukan karena adanya kelangkaan/keterbatasan sumber daya dan sumber dana yang tersedia sehingga tidak menyulitkan penentuan suatu pilihan kegiatan.

29. Budi Winarno. Loc.cit, hal 84

30. Solahudin Kusumanegara. Model dan Aktor Dalam Proses Kebijakan Publik. Gava Media. Yojyakarta. 2010, hal 53 
Waterson mengatakan bahwa pada hakikatnya, perencanaan adalah usaha yang dilakukan secara sadar, terorganisasi, dan terus menerus memilih alternatif yang terbaik dari sejumlah alternatif untuk mencapai tujuan tertentu. Sementara itu, Davidov dan Reiner mengemukakan bahwa perencanaan adalah suatu proses untuk menetapkan tindakan yang selayaknya. Dengan demikian, pilihan-pilihan yang tersedia akan membentuk suatu proses perencanaan yang terdiri atas tiga macam peringkat. Pertama, memilih tujuan dan syaratsyarat. Kedua, mengenai seperangkat alternatif yang bersifat konsisten dengan ketentuan-ketentuan umum tersebut serta memilih sesuatu alternatif yang dikehendaki. Ketiga, mengarahkan tindakan-tindakan yang mengarah pada pencapaian tujuan-tujuan yang telah ditentukan tersebut ${ }^{31}$.

Sedangkan unsur-unsur perencanaan yang baik adalah sebagai berikut ${ }^{32}$ :

1. Adanya asumsi-asumsi didasarkan pada fakta-fakta. Ini berarti bahwa perencanaan hendaknya disusun berdasarkan asumsiasumsi yang didukung dengan fakta-fakta atau bukti-bukti yang ada. Hal ini menjadi penting karena hasil perencanaan meru- pakan dasar bagi pelaksanaan suatu kegiatan atau aktivitas.

2. Adanya alternatif-alternatif atau pilihan-pilihan sebagai dasar penentuan kegiatan yang akan dilakukan. Ini berarti bahwa dalam menyusun rencana perlu memperhatikan berbagai alternatif pilihan sesuai kegiatan yang akan dilaksanakan.

3. Adanya tujuan yang ingin dicapai. Dalam hal ini perencanaan merupakan suatu alat/sarana untuk mencapai tujuan melalui pelaksanaan kegiatan.

4. Bersifat memprediksi sebagai langkah untuk mengantisipasi kemungkinan-kemungkinan yang dapat mempengaruhi pelaksanaan perencanaan.

5. Adanya kebijaksanaan sebagai hasil keputusan yang harus dilaksanakan".

Perencanaan yang baik harus memuat prinsip yang terdapat dalam dokumen perencanaan, yaitu ${ }^{33}$ :

"a. apa yang akan dilakukan, yang merupakan jabaran dari misi dan visi

b. bagaimana mencapai hal tersebut.

c. Siapa yang akan melakukan.

d. Lokasi aktivitas.

31. dalam Ateng Syafrudin. DPRD (Dewan Perwakilan Rakyat Daerah) Dari Masa ke Masa.1991. Bandung : Mandar Maju, hal 5

32. Bratakusumah, Deddy Supriady \& Riyadi. Perencanaan Pembangunan Daerah. Jakarta: PT. Gramedia Pustaka Utama. 2005, hal 3

33. Abe, Alexander. Perencanaan Daerah Partisipatif. 2005. Pembaruan, Yogyakarta, hal 31 
e. Kapan akan dilakukan dan berapa lama. Sumber daya yang dibutuhkan".

Berdasarkan definisi-definisi yang telah dikemukakan tersebut dapat dikatakan bahwa perencanaan diartikan sebagai kegiatan-kegiatan pengambilan keputusan dari sejumlah pilihan mengenai sasaran dan caracara yang akan dilaksanakan dimasa depan guna mencapai tujuan yang diinginkan serta pemantauan dan penilaian atas perkembangan hasil pelaksanaannya yang akan dilakukan secara sistematis dan berkesinambungan. Perencanaan merupakan sebuah proses aktivitas manusia dan organisasi mempunyai sebuah formulasi dalam mencapai tujuan. Dalam memformulasikan ini memperhatikan sumber daya yang ada dengan melakukan inventarisasi, riset dan survei.

Berbicara mengenai anggaran, Munandar mengatakan bahwa anggaran adalah suatu rencana yang disusun sistematis, meliputi seluruh kegiatan perusahaan yang dinyatakan unit moneter dan berlaku unt uk jangka waktu tertent $u^{34}$.
Sementara itu, yang dimaksud dengan anggaran menurut Suparmoko adalah suatu daftar atau pernyataan terperinci tentang pendapatan dan belanja negara yang diharapkan dalam jangka waktu tertentu (biasanya satu tahun $^{35}$. Anggaran mempunyai kedudukan yang penting dalam penyelenggaraan pemerintahan daerah. Mardiasmo berpendapat bahwa arti penting anggaran pemda (anggaran daerah) dapat dilihat dari dua aspek berikut ${ }^{36}$ :

1. Anggaran merupakan alat bagi pemda untuk mengarahkan dan menjamin kesinambungan pembangunan serta meningkatkan kualitas hidup masyarakat.

2. Anggaran diperlukan karena adanya kebutuhan dan keinginan masyarakat yang tak terbatas dan terus berkembang, sedangkan sumber daya yang ada terbatas. Anggaran diperlukan karena keterbatasan sumber daya (scarify resouces), pilihan (choice), dan trade offs.

Mengenai hubungan antar APBD dengan perencanaan pembangunan oleh Tjokoamidjojo digambarkan sebagai berikut ${ }^{37}$ :

34. M. Munandar Solaeman. Ilmu Sosial Dasar Teori dan Konsep Ilmu Sosial, 1986. Bandung: PT Eresco, hal 1

35. M. Suparmoko. Keuangan Negara Dalam Teori dan Praktek. 2000. BPFE Yogyakarta. Yogyakarta, hal 47

36. Mardiasmo. Akuntansi Sektor Publik. 2004. Penerbit Andi. Yogyakarta, hal 182

37. Bintoro Tjokroamidjojo. Pengantar Administrasi Pembangunan. 1995. LP3S. Jakarta, hal 166 
"Hubungan antara perencanaan dan anggaran belanja negara menjadi timbal balik. Disatu pihak, pencerminan dalam anggaran belanja negara menjamin kepastian pembiayaan, sedangkan di lain pihak perencanaan akan memberikan perhatian terhadap keterbatasan pembiayaan. Selain itu, juga perencanaan proyekproyek menjadi lebih berperhatian terhadap masalah ongkos (cost conscious)".

Dengan demikian, perencanaan dan penganggaran merupakan rang- kaian kegiatan dalam satu kesatuan. Penyusunan rencana perlu memperhatikan kafasitas fiskal yang tersedia hingga dalam penerapannya, konsekuensi atas integrasi kegiatan perencanaan pembangunan dan penganggaran perlu diperhatikan. Perencanaan dan penganggaran merupakan proses yang paling krusial dalam penyelenggaraan pemerintahan karena berkaitan dengan tujuan pemerintah itu sendiri. Perencanaan dan penganggaran merupakan proses yang terintegrasi sehingga output dari perencanaan adalah penganggaran. Berikut adalah gambaran mengenai keterkaitan antara perencanaan dan penganggaran.

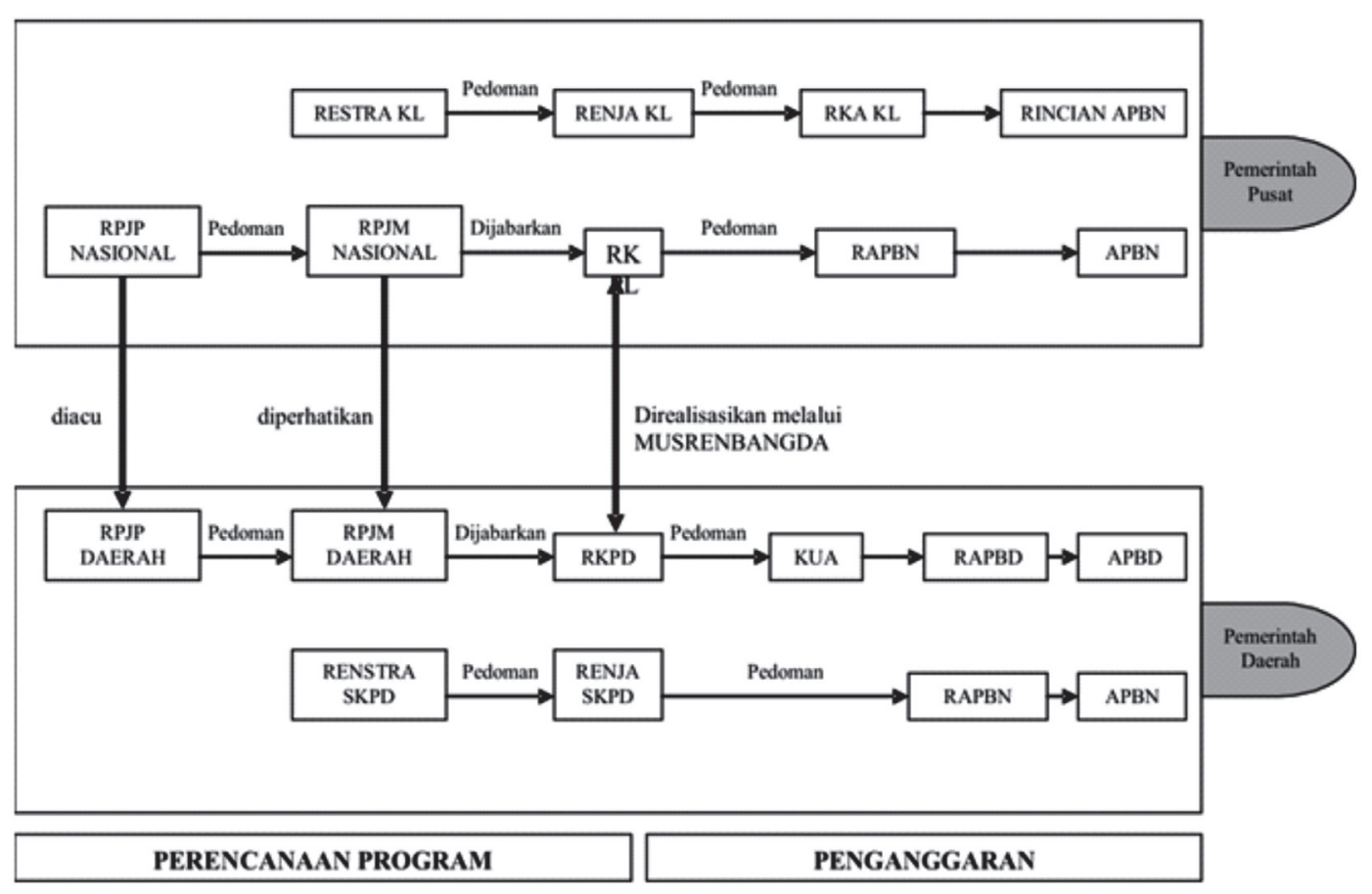

Gambar 1.1 Bagan Perencanaan dan Penganggaran 


\section{METODE PENELITIAN}

Penelitian ini menggunakan metode kualitatif. Dalam pandangan Cresswell (1994) pendekatan kualitatif adalah suatu proses penyelidikan untuk memahami masalah sosial dan manusia secara holistik yang dibentuk dengan kata-kata secara terinci terhadap orang dan pelaku yang diamati.

Pendekatan kualitatif menurut peneliti dianggap paling sesuai untuk meneliti bagaimana perumusan Anggaran dan Pendapatan Belanja Daerah (APBD) Kabupaten Sumedang. Sebab dalam penelitian ini, peneliti lebih menekankan pada penyelidikan untuk memahami masalah sosial berdasarkan pada pandangan informan yang terperinci tentang suatu masalah. Alasan lain menggunakan pendekatan kualitatif adalah penelitian tentang perumusan APBD ini merupakan suatu permasalahan yang harus dilihat sebagai suatu hal yang holistik, karena setiap aspek di dalamnya merupakan satu kesatuan yang tidak dapat dipisahkan dan juga penelitian tentang perumusan APBD ini tidak hanya melihat sesuatu yang tampak di atas permukaan saja, melainkan juga pada hal-hal yang ada di balik sesuatu yang tampak tersebut.
Alasan tersebut diperkuat oleh pendapat Arikunto, yakni peneliti sebagai instrumen mengandung makna peneliti tersebut memiliki daya responsif yang tinggi yaitu mampu merespon sambil memberikan interpretasi terus-menerus pada gejala yang dihadapi serta memiliki kemampuan dalam memandang objek penelitianya secara holistik, mengaitkan gejala dengan konteks saat itu, mengaitkan dengan masa lalu dan dengan kondisi lain yang relevan, "sehingga peneliti dapat melakukan analisis data sejak awal dengan melakukan interpretasi untuk memecahkan masalah yang dihadapi" 38

Sedangkan jenis metode penelitian yang digunakan dalam penelitian ini adalah metode penelitian deskriptif, hal ini dikarenakan kompleksnya permasalahan sosial yang ingin diteliti. Dengan menggunakan metode deskriptif, penulis dapat menjelaskan situasi sosial secara menyeluruh, luas dan mendalam, sehingga peneliti dapat menganalisis serta menginterpretasi data-data yang ditemukan dilapangan. Hal ini sesuai dengan yang diungkapkan oleh Moh. Nazir bahwa penelitian deskriptif adalah ${ }^{39}$ :

"Suatu metode dalam meneliti suatu status kelompok manusia,

38. Suharsimi Arikunto. Prosedur Penelitian Suatu Pendekatan Praktik. 2006. Jakarta : Rineka Cipta. hal 18

39. M. Nazir. 2005. Metodologi penelitian. Bogor : Ghalia Indonesia, hal 54 
suatu objek, suatu set kondisi, suatu sistem pemikiran ataupun suatu kelas peristiwa pada masa sekarang. Tujuan dari penelitian deskriptif ini adalah untuk membuat deskripsi atau gambaran atau lukisan secara sistematis, faktual dan akurat mengenai fakta - fakta, sifat - sifat serta hubungan antarfenomena yang diselidiki."

Sehingga dapat disimpulkan alasan penulis menggunakan metode deskriptif adalah penulis dapat menggambarkan objek penelitian juga menyorotinya secara lebih spesifik. Sehingga pengetahuan pada saat tertentu dapat dijelaskan secara lebih mendetail dan dicarikan solusi untuk memecahkan permasalahan yang timbul. Selain itu juga dengan menggunakan metode deskriptif penulis dalam penelitian yang penelaahannya pada suatu masalah secara intensif, mendalam, mendetail serta komprehensif sehingga upaya mencari solusi untuk permasalahan dalam perumusan Anggaran Pendapatan dan Belanja Daerah kabupaten Sumedang yang timbul dapat terwujud.

Guna memperoleh keterangan dan fakta-fakta selengkap mungkin dari keadaan empirik dalam penelitian ini maka penulis menggunakan beberapa teknik pengumpulan data. Menurut Sugiyono, ada beberapa macam teknik pengumpulan data dalam penelitian, yaitu observasi, wawancara, dan dokumentasi ${ }^{40}$. Dalam penelitian kualitatif, pengumpulan data dilakukan pada natural setting (kondisi alamiah), sumber data primer dan teknik pengumpulan data lebih banyak pada observasi serta wawancara mendalam dan dokumentasi.

Seorang peneliti harus memperhatikan siapa yang menjadi informannya. Informan merupakan sumber yang oleh peneliti dianggap mampu memberi informasi dan data. Adapun informan atau narasumber yang membantu dalam memberikan informasi yang rinci atas permasalahan penelitian ini, yakni sebagai berikut:

1. Tim Anggaran Pemerintah Daerah (TAPD) Kabupaten Sumedang, yakni Dinas Pendapatan Daerah (Dispenda), Badan Perencanaan dan Pembangunan Daerah (Bappeda), dan Badan Keuangan Daerah (Bakuda).

2. Panitia Anggaran DPRD (Panggar DPRD) Kabupaten Sumedang,

40. Sugiyono. Memahami Penelitian Kualitatif. 2007. Bandung: ALFABETA 
3. Forum Delegasi Musrenbang (FDM).

Untuk pengolahan dan analisa data, penulis menggunakan tahapan yang menurut Miles dan Huberman terdiri dari tiga alur kegiatan yang terjadi secara bersamaan, yaitu reduksi data, penyajian data, dan penarikan kesimpulan/verifikasi. reduksi data, penyajian data, dan penarikan kesimpulan/verifikasi sebagai sesuatu yang jalin menjalin merupakan proses suatu siklus dan interaktif pada saat sebelum, selama, dan sesudah pengumpulan data dalam bentuk sejajar untuk membangun wawasan umum yang disebut "analisis"

\section{HASIL DAN PEMBAHASAN}

\section{Proses Perumusan Kebijakan APBD Kabupaten Sumedang}

Perda No. 1 tahun 2007 tentang perencanaan dan penganggaran daerah yang berlaku di Kabupaten Sumedang, merupakan produk kebijakan lokal yang telah membuka sejarah baru dalam proses perumusan kebijakan anggaran di Kabupaten Sumedang. Perumusan kebijakan mengalami transformasi setelah dikeluarkannya perda ini. Salah satu upayanya adalah melalui dilembagakannya Forum Delegasi Musrembang (FDM) yang menjadi untuk mengawal amanat/aspirasi masayarakat dalam perumusan kebijakan. Selain itu perda ini memperjelas aliran dana yang diperuntukan langsung kepada masyarakat dengan diakomodasinya pagu indikatif kecamatan dan pagu indikatif sektoraL dalam pagu indikatif kewilayahan.

Forum Delegasi Musrenbang merupakan pelembagaan keterwakilan masyarakat dalam proses penganggaran. FDM beranggotakan delegasi sektoral maupun kewilayahan yang berfungsi mengawasi proses penganggaran pasca prose perencanaan.

Forum ini dibentuk dari perwakilan peserta musrenbang di tingkat desa yang mewakili proses musrenbang di tingkat kecamatan hingga tingkat kabupaten. Pengawasan FDM dimulai pada saat dilakukan forum konsultasi publik untuk mengesahkan rancangan KUA, PPAS, dan RAPBD.

Pelembagaan FDM sebagai sebuah Institusi yang harus ada sesuai dengan amanat Perda No. 1 Tahun

41. Ulbert Silalahi. Metode Penelitian Sosial. 2006. Bandung : UNPAR PRESS, hal 113 
2007 merupakan sebuah proses untuk membuka ruang publik dalam proses perumusan Anggaran di Kabupaten Sumedang. Sampai saat ini ada dua cara untuk menjadi anggota FDM:

1. Sebagai delegasi kewilayahan yang dipilih dari delegasi masyarakat tingkat kecamatan yang sebelumnya dipilih dari delegasi masyarakat tingkat desa.

2. Sebagai delegasi sektoral yang dipilih dari forum SKPD di tiaptiap SKPD. Anggota FDM terpilih kemudian harus dilibatkan dalam konsultasi publik tentang pembahasan rancangan KUA, PPAS, dan APBD yang diselenggarakan oleh DPRD.

Sehingga dapat dikatakan Anggota FDM tersebut berasal dari semua perwakilan di kecamatan yang ada di Kabupaten Sumedang. Beberapa anggota berasal dari pegawai negri sipil non struktural namun pada dasarnya mereka dipilih oleh masyarakat untuk mewakili mereka pada Forum delegasi Musrenbang.

Sedangkan pagu indikatif kewilayahan merupakan rancangan awal program prioritas dan patokan batas maksimal anggaran yang diberikan kepada SKPD. Pagu indikatif tersebut dirinci berdasarkan plafon anggaran sektoral dan plafon anggaran kecamatan. Pagu indikatif kewilayahan ini memuat rancangan awal program pembangunan prioritas, dan patokan maksimal anggaran yang diberikan kepada SKPD dan dirinci berdasarkan program wilayah desa/kelurahan serta wilayah kecamatan.

Penetapan Pagu indikatif ini dilakukan sebelum proses Musrenbang, yang didasarkan pada indikator pembangunan dengan mengacu pada perkiraan maju yang telah disetujui pada tahun sebelumnya, evaluasi pencapaian RPJMD sampai dengan tahun berjalan, sumber daya yang tersedia, dan kondisi aktual daerah.

Pagu indikatif terdiri dari pagu indikatif sektoral dan pagu indikatif Kecamatan. Pagu indikatif sektoral merupakan patok batas maksimal anggaran yang diberikan kepada SKPD dan penentuan alokasi belanjanya ditentukan oleh mekanisme teknokratik SKPD dengan berdasarkan kepada kebutuhan dan prioritas program. Sedangkan pagu indikatif Kecamatan adalah sejumlah patokan atau batas maksimal anggaran yang diberikan kepda SKPD yang penentuan alokasi belanjanya ditentukan oleh mekanisme partisipatif melalui Musrenbang Kecamatan dengan berdasarkan kepada kebutuhan dan prioritas program.

Pagu indikatif sektoral menjadi salah satu pedoman pembatasan plafon anggaran SKPD untuk menentukan alokasi anggarannya, dan pagu indikatif kecamatan menjadi pedoman pembatasan plafon anggaran masyarakat dan SKPD kecamatan dalam menyusun kebutuhan masyarakatnya ditingkat desa hinggá kecamatan. 
Forum Delegasi Musrenbang (FDM) dan pagu indikatif merupakan dua hal penting yang menjadi inovasi dalam Perda no 1 tahun 2007 tentang perencanaan dan penganggaran daerah di Kabupaten Sumedang. Keduanya merupakan inisaitif kebijakan lokal dalam upaya mewujudkan proses penganggaran yang bebasis pada prinsip-prinsip demokrasi lokal dan goods governance dengan 4 pilar utama yaitu partisipatoris, Transparansi, Accoutability, dan predictability.

Sehingga APBD merupakan pilot projec dari perda no 1 tahun 2007. Karena dalam APBD Kabupaten Sumedang mulai menerapkan pagu indikatif kewilayahan dan pagu sektoral untuk semua SKPD. Serta menjadi awal berfungsinya Forum Delegasi Musrenbang sebagai oraginasi masyarakat yang mengawal semua aspirasi masyarakat yang telah ditetapkan di musrenbang desa hingga kabupaten

Adapun proses perumusan kebijakan APBD berdasarkan perda No. 1 tahun 2007 di Kabupaten Sumedang dapat dijelaskan mulai dari tahapan-tahapan sebagai berikut:

1. Pelaksanaan Musrenbang Desa, Kecamatan, dan Kabupaten sebagai tahap pertama untuk merumuskan masalah kebijakan APBD tahun anggaran secara berjenjang.

Musrenbang baik ditingkat desa/ kelurahan, kecamatan dan kabupaten yang ada di Kabupaten Sumedang adalah untuk mendorong partisipasi masyarakat dalam merumuskan masalah pembangunan dan mengambil keputusan bersama-sama pemerintah dalam melaksanakan perencanaan pembangunan di tingkat desa/ kelurahan, kecamatan, dan kabupaten. Dengan adanya musrenbang dari tingka desa hingga tingkat kabupaten, pemerintah dan masyarakat dapat melakukan koordinasi, konfirmasi, serta klarifikasi usulan dalam agenda kebijakan pemerintah yang sudah direncanakan oleh SKPD Kabupaten Sumedang.

Musrenbang tahunan di tingkat desa/kelurahan untuk merumuskan kebijakan APBD di Kabupaten Sumedang dilakukan dengan menggunakan dokumen Renstra dan dokumen RKPD sebagai referensi awal dalam menentukan kebutuhankebutuhan masyarakat. Musrenbang di tingkat desa itu dihadiri oleh Ketua Bappeda, kepala desa, tokoh-tokoh masyarakat, aktivis LSM, serta anggota masyarakat yang memiliki kepentingan untuk hadir dalam acara tersebut. Beberapa anggota DPRD juga hadir pada musrenbang tingkat desa untuk mendengar aspirasi kebutuhan masyarakat.

Tahap ini merupakan tahap penghimpunan data dasar sebagai pengenalan kebutuhan, permasalahan, dan sumber daya yang dimiliki. Proses pengidentifikasian kondisi lokal tersebut dilakukan oleh setiap desa/ 
kelurahan yang ada di kabupaten Sumedang. Musrenbang desa ini menghasilkan keluaran berupa daftar usulan kegiatan masyarakat yang dibagi kedalam 2 kategori, yaitu program pembangunan skala desa yang didanai oleh dana alokasi untuk desa (DADU) dan program pembangunan yang menjadi tanggung jawab SKPD.

Program ini dibawa oleh tiga orang delegasi musrenbang desa yang dipilih di antara peserta musrenbang desa yang kemudian dibahas pada musrenbang ditingkat kecamatan. Setelah Dokumen itu disahkan oleh Kepala Desa/Lurah dan disetujui oleh Ketua BPD dan Ketua Delegasi Desa/ kelurahan, dokumen tersebut menjadi bahan utama Musrenbang Tahunan Wilayah Kecamatan. Peserta Musrenbang Tahunan di tingkat desa/ kelurahan memilih tiga orang Delegasi Masyarakat Desa/Kelurahan untuk mengikuti Musrenbang Kecamatan. Yang diantaranya harus menempatkan proporsional $40 \%$ untuk delegasi perempuan. Jadi dalam tiga delegasi ini terdapat paling tidak satu orang delegasi perempuan.

Sebelum musrenbang di tingkat kecamatan dimulai, Bappeda merumuskan pagu indikatif baik sektoral maupun kecamatan. Setelah pagu indikatif selesai dirumuskan, Bupati menyampaikan pagu indikatif tersebut kepada DPRD untuk kemudian dibahas bersama dan selanjutnya dituangkan dalam nota kesepakatan. Nota kesepakatan itu disosialisasikan kepada masyarakat wilayah kecamatan sebagai bahan untuk menyelenggarakan musrenbang kecamatan dan kepada masyarakat sektoral serta SKPD sebagai bahan menyusun rancangan awal Renja SKPD.

Adapun anggaran yang bersentuhan dengan kepentingan publik terlihat dari pagu Indikatif Kewilayahan yang merupakan ruang untuk menjaring partisipasi publik didalam kebijakan anggaran yang berkaitan dengan kepentingan publik di suatu wilayah. Sehingga besar dana yang terakumulasi didalam pagu Indikatif menunjukan besarnya anggaran yang diperuntukan bagi kepentingan publik.

Selanjutnya pada saat musrenbang kecamatan disesuaikan dengan kebutuhan masyarakat yang berhasil dijaring pada saat saat dilaksanakan musrenbang desa. Hasil kesepakatan ini menjadi bahan yang kemudian dibahas dalam musrenbang Kabupaten Sumedang.

Secara umum musrenbang di tingkat desa/kelurahan hingga kecamatan berlangsung dengan baik, aspirasi masyarakat dapat diserap dengan baik dan representatif. Hal ini dapat dilihat dari komposisi peserta dan pihak-pihak yang terlibat dalam proses tersebut yang mencakup berbagai elememen yang dapat dikatakan dapat mewakili semua komponen penting dalam masyarakat 
setempat. Jumlah pesertanya juga memadai dan kedudukan masingmasing peserta musyawarah itu relative sejajar satu sama lainnya dan terlibat secara aktif sejak awal pembahasannya. Kedudukan dan peranan desa/kelurahan hanya sebagai fasilitator yang sejajar dengan peserta lainnya. Waktu penyelenggaraanya juga relative cukup memadai. Dengan kondisi demikian dapat diasumsikan proses Musrenbang ditingkat desa hingga kabupaten berjalan secara komunikatif, membumi dan egalitarian.

Musrenbang Kecamatan dihadiri oleh unsur Muspika, pemerintah kecamatan, perwakilan musrenbang desa, dan anggota DPRD masingmasing Dapil (Daerah Pemilihan). Disamping itu terdapat narasumber yang terdiri dari tim panitia anggaran pemerintah daerah Kabupaten Sumedang yang diwakili oleh Bappeda, perwakilan SKPD Kabupaten Sumedang, Camat dan perwakilan dari lembaga swadaya masyarakat yang ada di Kabupaten Sumedang.

Pada acara tersebut, dilakukan pembahasan mengenai usulan-usulan program pembangunan yang diusulkan oleh setiap desa serta penetapan pagu anggaran untuk setiap program yang telah disepakati. Proses musrenbang kecamatan ini berlangsung dengan tertib dan aman. Para peserta menilai musrenbang kecamataan pada saat itu sebagai musrenbang yang berbeda dengan musrenbang yang sebelumnya.
Musrenbang saat itu merupakan musrenbang yang terbuka, transparan dan aspiratif.

Hasil Musrenbang Kecamatan tersebut menjadi bahan dalam musrenbang Kabupaten. Musrenbang kabupaten ini dihadiri oleh perwakilan dari gubernur, unsur Muspika, pemerintah kecamatan, perwakilan musrenbang desa, dan anggota DPRD. Pada musrenbang ini semua peserta tidak terlalu lama membahas hasil musrenbang kecamatan, peserta lebih sibuk membicarakan tent ang programprogram yang akan di bawa pada saat musrenbang provinsi dan musrenbang nasional. Sehingga hasil musrenbang Kecamatan tidak berbeda dengan hasil musrenbang Kabupaten.

Jika dilihat dari proses pelaksanaanya, musrenbang ditingkat kecamatan dan kabupaten/kota, berbeda dengan musrenbang di tingkat desa/kelurahan. Jika dilihat dari perspektif keterlibatan at au partisipasi masyarakat, pada tingkat ini biasanya masyarakat tidak lagi terlibat secara aktif, tetapi hanya diwakilkan oleh orang-orang yang dianggap mewakili aspirasi mereka.

Mekanisme pemilihan perwakilan itu di Kabupaten Sumedang biasanya tidak terlalu rumit. Perwakilan itu mendapatkan legitimasi kepercayaan masyarakat secara formal maupun informal. Orang-orang yang menjadi wakil masyarakat pada saat musrenbang adalah tokoh-tokoh masyarakat yang memiki kedekatan 
yang intens dengan masyarakat dan memiliki lat ar belakang yang beragam.

\section{Penyusunan Renja SKPD, RKPD, dan RKA SKPD sebagai tahap penyusunan agenda kebijakan APBD}

Proses penetapan agenda kebijakan APBD di Kabupaten Sumedang, dapat diamati pada saat penyusunan Rencana Kerja SKPD yang kemudian ditetapkan menjadi Rencana Kerja Pemerintah Daerah. Pemerintah daerah yang diwakili oleh Bappeda memfasilitasi forum SKPD untuk memproses hasil musrenbang Kecamatan untuk menjadi Renja SKPD. Proses itu dilakukan setelah nota pagu indikatif kecamatan dan pagu Indikatif SKPD disepakati.

Dokumen hasil musrenbang Kecamatan tersebut disahkan oleh camat dan disetujui oleh Ketua delegasi masyarakat Wilayah Kecamatan, dan diketahui oleh anggota DPRD dari wilayah pemilihan Kecamatan yang bersangkutan, dokumen tersebut menjadi bahan utama dalam forum SKPD.

Forum SKPD menjadi pertemuan untuk menyortir hasil kompilasi usulan kecamatan yang masuk ke sektor yang menjadi bidang SKPD. Hasilnya yaitu Renja SKPD yang disiapkan untuk dibahas didalam Musrenbang tingkat kabupaten. Kepala SKPD menggunakan Dokumen hasil forum SKPD sebagai bahan penyempurnaan Rancangan Awal Renja SKPD menjadi Renja SKPD.
Saat forum ini diselenggarakan, semua jajaran muspika hadir, serta beberapa tokoh masyarakat dan kalangan aktivis lembaga swadaya masyarakat yang memiliki konsentrasi terhadap kebijakan anggaran di Kabupaten Sumedang. Forum ini mensosialisasikan program-program dari masing-masing SKPD dan pagu sektoral yang sudah ditetapkan untuk masing-masing SKPD.

Renja SKPD tersebut kemudian menjadi bahan utama didalam Musrenbang Kabupaten Sumedang. Musrenbang Kabupaten diikuti oleh unsurunsur pemerintah Daerah, Delegasi Musrenbang Wilayah Kecamatan, Bappeda Provinsi, dan Kementrian/ Lembaga yang terkait. Setelah musrenbang Kabupaten selesai maka didapatlah Rencana Kerja Pemerintah Daerah (RKPD yang kemudian diajukan kepada Bupati untuk ditetapkan oleh peraturan Kepala Daerah.

Pada acara tersebut pembahasan mengenai rencana kerja SKPD tidak terlalu alot, peserta musrenbang lebih banyak membahas tentang agendaagenda kegiatan yang akan dibawa pada tingkat musrenbang provinsi dan nasional. Sehingga rencana SKPD tidak mengalami pembahasan yuang cukup lama. Peserta terlihat hanya mempertanyakan tentang aspirasiaspirasi yang masuk menjadi renja SKPD dan RKPD.

Tahap ini dimulai setelah Bupati menyusun rancangan kebijakan umum anggaran untuk berdasarkan pagu 
indikatif, RKPD dan RKA SKPD. Adapun Rancangan KUA tersebut memuat poin-poin sebagai berikut :

a. uraian kondisi atau prestasi yang telah dicapai pada tahun sebelumnya dan perkiraan pencapaian pada tahun anggaran yang akan datang,

b. identifikasi masalah dan tantangan utama yang akan dihadapi pada tahun yang akan datang,

c. identifikasi prioritas-prioritas upaya/cara yang direncanakan untuk menyelesaikan masalah atau menjawab tantangan yang mendesak dan berdampak luas bagi kesejahteraan masyarakat serta mendukung upaya menciptakan kondisi pada RPJMD,

d. target/kondisi yang diharapkan akan diperoleh/dicapai yang dihasilkan dari pelaksanaan program /kegiatan pada tahun yang akan datang,

e. kondisi yang telah terjadi dan asumsi yang diperkirakan akan terjadi untuk mendanai seluruh pengeluaran.

Kepala Daerah menyampaikan rancangan KUA kepada DPRD pada pertengahan tahun anggaran berjalan. Kemudian Rancangan KUA yang telah disampaikan Kepala Daerah dibahas bersama antara DPRD dengan Pemerintah Daerah.

Pada saat pembahasan rancangan KUA tersebut DPRD menyelenggarakan konsultasi publik untuk mendapat masukan dari masyarakat khususnya Forum Delegasi Musrenbang (FDM) dan unsur stakeholders lainnya. Biasanya pada tahapan ini terjadi pertarungan kepentingan antara aktor-aktor yang terlibat dalam perumusan kebijakan. Pertarungan itu muncul karena banyaknya aspirasi masyarakat yang menghilang pada saat pembuatan rancangan KUA, serta banyaknya agenda-agenda yang tidak pernah ada dalam musrenbang sengaja dimasukan di dalam rancangan KUA untuk kepentingan politis.

Namun pada saat konsultasi publik yang dilakukan DPRD untuk membahas rancangan KUA. relatif tidak terjadi perdebatan yang alot antara aktor-aktor pembuat kebijakan yang hadir pada saat itu, baik DPRD, FDM, maupun pemerintah daerah tidak terlalu berdebat mengenai subtasi KUA. Forum Delegasi Musrenbang (FDM) melihat adanya kondisi yang positif, menurut mereka pihak DPRD dan Pemerintah Derah Kabupaten Sumedang memiliki itikad baik dengan tidak menghilangkan hasil-hasil kesepakatan musrenbang desa hingga kabupaten. Mereka menganggap kebiasan-kebiasaan buruk legislatif dan eksekutif pada saat menghilangkan hasil-hasil musrenbang untuk kepentingan pribadi dan golongan tertentu sudah berakhir.

Setelah perdebatan berakhir, rancangan KUA yang telah dibahas bersama DPRD dan telah dikonsultasikan kepada publik selanjutnya dibahas oleh fraksi sebelum disepakati 
sebagai Kebijakan Umum Anggaran (KUA)

\section{Penetapan Kebijakan Umum APBD (KUA) dan Prioritas dan Plafon Anggaran Sementara (PPAS) sebagai tahap pemilihan alternatif kebijakan untuk memecahkan masalah}

Tahap ini dilakukan sebagai upaya memilih alternatif kebijakan yang solutif untuk memecahkan berbagai masalah setelah masalahmasalah publik didefinisikan dengan baik serta solusi-solusi permasalahan disepakati didalam agenda kebijakan.

Berdasarkan kebijakan umum yang telah disepakati, Pemerintah Daerah melakukan Pembahasan prioritas dan plafon penyusunan Rancangan PPAS untuk. Rancangan PPAS tersebut memuat antara lain:

a. skala prioritas untuk urusan wajib dan urusan pilihan,

b. urutan program untuk masingmasing urusan,

c. plafon anggaran sementara untuk masing-masing program.

PPAS tersebut disampaikan Bupati kepada DPRD untuk dibahas. Pembahasan tersebut dilakukan oleh TAPD bersama Panitia Anggaran DPRD. Dalam pembahasan rancangan PPAS, DPRD menyelenggarakan konsultasi publik untuk mendapat masukan dari masyarakat khususnya Forum Delegasi Musrenbang dan unsur stakeholders lainnya. Pada konsultasi publik ini tidak terdapat perdebat an yang cukup alot, rancangan PPAS yang telah dibahas dan disepakati DPRD selanjutnya disepakati menjadi PPA.

Prioritas dan Plafon Anggaran (PPA) ditetapkan oleh Bupati berdasarkan PPAS yang telah disepakati bersama-sama dengan DPRD sebagai dasar penyusunan rencana kerja dan anggaran satuan kerja perangkat daerah (RKA-SKPD).

Kepala SKPD menyusun RKASKPD berdasarkan pedoman penyusunan RKA SKPD. RKA-SKPD disusun dengan menggunakan pendekatan kerangka pengeluaran jangka menengah daerah, penganggaran terpadu dan penganggaran berdasarkan prestasi kerja. Penyusunan RKASKPD dengan pendekatan kerangka pengeluaran jangka menengah dilaksanakan dengan menyusun prakiraan maju yang berisi perkiraan kebutuhan anggaran untuk program dan kegiatan yang direncanakan dalam tahun anggaran berikutnya dari tahun anggaran yang direncanakan dan merupakan implikasi kebutuhan dana untuk pelaksanaan program dan kegiatan tersebut.

RKA-SKPD memuat rencana pendapatan, belanja untuk masingmasing program dan kegiatan menurut fungsi untuk tahun yang direncanakan dirinci sampai dengan rincian objek pendapatan, belanja dan pembiayaan serta prakiraan maju untuk tahun berikutnya. RKA-SKPD yang telah 
disusun oleh kepala SKPD disampaikan kepada PPKD untuk dibahas oleh tim anggaran pemerintah daerah. Pembahasan itu dilakukan untuk menelaah kesesuaian antara RKA SKPD dengan KUA, PPAS, prakiraan maju yang telah disetujui pada tahun sebelumnya, dan dokumen perencanaan lainnya, serta capaian kinerja, indikator kinerja, analisis standar belanja, standar satuan harga, dan standar pelayanan minimal.

PPKD menyusun rancangan peraturan daerah tentang APBD berikut dokumen pendukung berdasarkan RKA SPKD yang telah ditelaah oleh tim anggaran pemerintah daerah. Dokumen pendukung Itu terdiri atas nota keuangan dan rancangan APBD.

Rancangan peraturan daerah tentang APBD yang telah disusun oleh PPKD disampaikan kepada Bupati DPRD yang sebelumnya disosialisasikan kepada masyarakat. Penyebarluasan rancangan peraturan daerah tentang APBD dilaksanakan oleh sekretaris daerah selaku koordinator pengelolaan keuangan daerah. Setelah itu Bupati menyampaikan rancangan peraturan daerah tentang APBD kepada DPRD disertai penjelasan dokumen pendukungnya untuk dibahas dalam rangka memperoleh persetujuan bersama.

\section{Penetapan Rancangan Ang- garan Pendapatan dan Belanja Daerah (APBD) menjadi APBD sebagai tahap penetapan kebijakan anggaran}

Untuk melakukan pembahasan rancangan peraturan daerah tentang APBD DPRD menyelenggarakan konsultasi publik agar mendapat masukan dari masyarakat khususnya Forum Delegasi Musrenbang (FDM) dan unsur stakeholder lainnya. Konsultasi tersebut dilakukan untuk meminta saran dari berbagai kalangan terhadap rancanagan APBD.

Berdasarkan hasil konsultasi publik tersebut, Rancangan APBD Kabupaten Sumedang sudah sesuai dengan aspirasi masyarakat, karena menurut FDM rancangan APBD tersebut telah mengakomodir semua aspirasi masyarakat yang sudah didapatkan dari tingkat desa hingga tingkat kabupaten. FDM dan berbagai stakeholder lainnya hanya mengingatkan kembali pemerintah untuk lebih konsisten dalam menjalankan rancangan tersebut bila sudah ditetapkan menjadi APBD. Jangan sampai terjadi berbagai perkeliruan pada saat implementasi kebijakan tersebut, sehingga semua aspirasi masyarakat dapat terwujud dan masyarakat tidak lagi drugikan oleh ulah pejabat yang korup.

Setelah konsultasi publik selesai dilakukan, tim anggaran pemerintah daerah Kabupaten Sumedang melaporkan kemajuan yang terjadi 
selama pembahasan Raperda APBD di hadapan seluruh anggota DPRD Kabupaten Sumedang, Gubernur, dan tim asistensi eksekutif. Dalam laporan singkatnya ketua tim anggran pemerintah daerah melaporkan kemajuan-kemajuan yang terjadi ketika pembahasan Raperda APBD, mulai dari saat Raperda ini masuk ke DPRD kemudian kembali dirumuskan oleh tim. Adapun kemajuan-kemajuan yang disampaikan oleh ketua tim anggaran pemerintah daerah adalah mulai adanyakejelasan untukpengalokasiaan anggaran setelah adanya pagu indikatif kecamatan maupun SKPD sehingga pembahasan Raperda APBD tidak terlalu menghabiskan waktu yang terlalu lama, karena tidak ada bagian Raperda APBD tahun anggaran yang harus dirubah.

Laporan singkat tersebut ditanggapi melalui penyampaian pandangan akhir fraksi. Pandangan akhir itu berisikan pandangan akhir fraksi tentang Raperda APBD. Semua fraksi memutuskan untuk menerima sepenuhnya raperda APBD dan memutuskan agar Raperda APBD segera di sahkan sebagai APBD.

\section{SIMPULAN DAN SARAN}

\section{Simpulan}

Proses Perumusan Kebijakan Anggran Pendapatan dan Belanja Daerah di Kabupaten Sumedang diatur berdasarkan Perda No 1 tahun
2007. Dimulai dengan musrenbang desa, kecamatan dan kabupaten sebagai bagian dari proses perumusan masalah kebijakan anggaran secara berjenjang; penetapan renja SKPD sebelum musrenbang kabupaten dan penetapan RKPD dan KUA sebagai bagian dari penetapan agenda kebijakan anggaran; Penetapan PPAS dan pembuatan rancangan APBD; serta penetapannya menjadi kebijakan APBD. Perda ini telah membuat terobosan baru dalam proses perumusan kebijakan APBD dengan dilembagakannya Forum Delegasi Musrenbang(FDM) dan diterapkannya pagu indikatif kewilayahan dan pagu indikatif sektoral. Luasnya partisipasi masyarakat dan keterbukaan proses perumusan kebijakan anggaran merupakan awal yang positif untuk membentuk good governance pada pemerintah Daerah Kabupaten Sumedang.

Sebelum musrenbang kecamatan berakhir, Pagu indikatif Kecamatan ditetapkan di dalam musrenbang kecamatan, sedangkan pagu indikatif sektoral ditetapkan sebelumnya melalui perhitungan yang sudah ditentukan. Dampak yang terasa dari adanya pagu indikatif kecamatan dan sektoral adalah transpormasi pola musrenbang dari penyaluran aspirasi keinginan menjadi kebutuhan, adanya kejelasan anggaran untuk masyarakat, memudahkan pengawasan terhadap implementasi program pemerintah sehingga angaran mengalir langsung pada masyarakat. 


\section{Saran}

Keterbukaan dan pola akomodatif yang luas terhadap partisipasi masyarakat dalam perumusan kebijakan harus tetap dipertahankan karena hal itu dapat meminimalisir penyimpangan-penyimpangan yang biasa terjadi dalam perumusan anggaran daerah Kabupaten Sumedang. Hal ini merupakan awal yang positif dalam upaya membangun good governance pada pemerintahan Kabupaten Sumedang.

\section{DAFTAR PUSTAKA}

Alexander, Abe. 2005. Perencanaan Daerah Partisipatif. Pembaruan. Yogyakarta.

Arikunto, Suharsimi. Prosedur Penelitian Suatu Pendekatan Praktik. 2006. Jakarta: Rineka Cipta.

Bidiarjo, Miriam. 1989. Dasar-dasar Ilmu Politik. Jakarta : Raja Grafindo.

Bratakusumah, Deddy Supriady \& Riyadi. 2005. Perencanaan Pembangunan Daerah. Jakarta: PT. Gramedia Pustaka Utama.

Dunn, William N. 2003 Pengantar Analisis Kebijakan Publik. Yogyakarta: Gajah Mada University Press.

Furchan, Arif. 1992. Pengantar Metode Penelitian Kualitatif. Surabaya : PT. Usaha Nasional.
Hoessein, Bhenjamin, dkk. 2005. Naskah Akademik Tata Hubungan Kewenangan Pemerintah Pusat dan Daerah. Jakarta: Pusat Kajian Pembangunan Administrasi Daerah dan Kota, FISIP UI.

Islamy, Irfan. 2004. Prinsip-Prinsip Perumusan Kebijakan Negara. Jakarta : Bina Aksara.

Kaho, Josep Riwu. 1997. Prospek Otonomi Daerah di Republik Indonesia. JAKARTA: Raja Grafindo.

Koentjaraningrat,1982. MetodeMetode Penelitian Masyarakat, Jakarta. Gramedia.

Kusumanegara, Solahudin. 2010. Model dan Aktor dalam Proses Kebijakan Publik. Yogyakarta: Gava Media

M. Nazir. 2005. Metodologi penelitian. Bogor: Ghalia Indonesia.

Maschab, Mashuri. 1993. Kekuasaan Legislatif di Indinesia. Jakarta : Bina Aksara.

Sanit, Arbi. 1985. Perwakilan Politik di Indonesia. Jakarta: PT. Rajawali.

Sarundajang. 2000. Arus Balik Kekuasaan Pusat ke Daerah. Jakarta : Pustaka Sinar Harapan.

Silalahi, Ulbert. 2006. Metode Penelitian Sosial. Bandung : UNPAR PRESS

Soejito, Irawan. 1989. Teknik Membuat Peraturan Daerah. Jakarta : Bina Aksara. 
Soekanto, Soerjono,2002. Sosiologi:

Suatu Pengantar, Jakarta. PT. Raja Grafindo Persada.

Solaeman, M. Munandar, 1986. Ilmu

Sosial Dasar Teori dan Konsep Ilmu Sosial, Bandung: PT Eresco

Subarsono, AG. 2006. Analisis

Kebijakan Publik Konsep Teori dan Aplikasi. Yogyakarta : Pustaka Pelajar.

Sugiyono. 2007. Memahami Penelitian

Kualitatif. Bandung: ALFABETA

Suparmoko, M. 2000. Keuangan Negara Dalam Teori dan Praktek. BPFE Yogyakarta. Yogyakarta.

Surakhmad, Winarno. 1991. Pengantar Penulisan Ilmiah Dasar, Metode dan Teknik. Bandung : Tarsito.
Syafrudin, Ateng. 1991. DPRD (Dewan Perwakilan Rakyat Daerah)Dari Masa ke Masa. Bandung : Mandar Maju.

Syafrudin, Ateng. 1991. Hubungan Kepala Daerah Dengan DPRD. Bandung : Tarsito.

Wasistiono, Sadu. 2001. Etika Hubungan Eksekutif-Legislatif dalam Rangka Otonomi Daerah. Bandung : Pusat Kajian STPDN.

Winarno, Budi. 2002. Teori dan Proses Kebijakan Publik. Yogyakarta : Media Pressindo. 